\title{
Seroprevalence of rickettsia spp. and a study of the tick fauna in dogs from the municipality of Seropédica, State of Rio de Janeiro
}

\section{Soroprevalência de rickettsia spp. e estudo da fauna de carrapatos em cães no Município de Seropédica, Estado do Rio de Janeiro}

\author{
Matheus Dias Cordeiro ${ }^{1}$; Vanessa de Almeida Raia'; ${ }^{2}$ Adriano Pinter ${ }^{3}$; Nathalie \\ Costa da Cunha ${ }^{4}$; Celso Eduardo de Souza ${ }^{3}$; Adivaldo Henrique da Fonseca ${ }^{5 *}$
}

\begin{abstract}
The aim of this study was to investigate the presence of anti-Rickettsia spp. antibodies in dogs, the tick fauna, and the ticks that are carriers of rickettsiae of the spotted fever group (SFG). About 68 (24\%) of the 283 serum samples tested by indirect immunofluorescence (IFA) reacted against the $R$. rickettsii crude antigen. The titers varied between 1:64 and 1:512. At the time of collection, 189 (64.5\%) of the 293 dogs included in this study, were infested with ticks. Ticks classified as Rhipicephalus sanguineus and Amblyomma sculptum were identified. None of the ticks examined for SFG rickettsiae using polymerase chain reaction (PCR) were positive. The presence of the anti- $R$. rickettsii antibodies detected by IFA, albeit at low titers, suggests the circulation of SFG rickettsiae, which requires permanent surveillance because there are records on human fatalities related to spotted fever and to avoid any future threats to the students moving extensively in the areas near of the Rural Federal University of Rio de Janeiro.
\end{abstract}

Key words: Spotted fever, Rickettsia, zoonosis, dogs

\section{Resumo}

Este estudo teve como objetivos investigar a presença de anticorpos anti-Rickettsia spp., a fauna de carrapatos e a ocorrência de riquétsias do grupo da febre maculosa em carrapatos coletados em caninos do município de Seropédica, estado do Rio de Janeiro. Dos 283 soros testados pela imunofluorescência indireta (IFI), 68 (24\%) apresentaram reatividade contra antígeno bruto de $R$. rickettsii. A titulação variou entre 1:64 à 1:512. Dos 293 cães avaliados, 189 (64,5\%) estavam infestados por carrapatos no momento da coleta. Foram identificados carrapatos das espécies Rhipicephalus sanguineus e Amblyomma sculptum. Nenhum carrapato examinado por meio da reação em cadeia de polimerase (PCR) apresentou-se positivo. A presença de anticorpos contra $R$. rickettsii pela IFI, mesmo que em baixos títulos, sugere a circulação de rickettsias do grupo da Febre Maculosa, devendo-se ter uma vigilância permanente devido ao grande trânsito de alunos nas áreas próximas ao campus da UFRRJ e ao registro da ocorrência de óbitos em humano por Febre Maculosa.

Palavras-chave: Febre maculosa, rickettsia, zoonoses, caninos

1 Discente do Curso de Doutorado do Curso de Pós-Graduação em Ciências Veterinárias, Universidade Federal Rural do Rio de Janeiro, UFRRJ, Seropédica, RJ, Brasil. E-mail: mathcordeiro@hotmail.com

2 Discente de Pós-Doutorado, Dept ${ }^{\circ}$ de Epidemiologia e Saúde Pública, Instituto de Veterinária, UFRRJ, Seropédica, RJ, Brasil. E-mail: vanessaraiaufrrj@gmail.com

3 Pesquisadores, Drs., Superintendência de Controle de Endemias do Estado de São Paulo, Mogi Guaçu, SP, Brasil. E-mail: apinter@sucen.sp.gov.br; celsoesouza@gmail.com

4 Prof $^{\mathrm{a}}$ Dr $^{\mathrm{a}}$, Dept ${ }^{\mathrm{o}}$ de Saúde Coletiva Veterinária e Saúde Pública, Universidade Federal Fluminense, UFF, Santa Rosa, Niterói, RJ, Brasil. E-mail: nathalie.cunha@gmail.com

5 Prof. Titular, Curso de Pós-Graduação em Ciências Veterinárias, UFRRJ, Seropédica, RJ, Brasil. E-mail: adivaldo@ufrrj.br Author for correspondence 
Spotted fever is a highly lethal zoonotic disease in humans that is caused by the Rickettsia rickettsii bacteria; it was initially described in the United States by Howard Taylor Ricketts in 1909. The Rickettsia genus, belonging to the Rickettsiaceae family, includes species of gram-negative bacteria that are obligate intracellular parasites with short viability outside the host cells. These organisms reproduce in nucleated cells, mainly endothelial cells, causing multi-systemic vasculitis in small arteries, veins, and capillaries (PAROLA et al., 2013).

In Brazil, the disease caused by this bacterial species was first described in the 1920s; it was initially called "typhus exanthematicus" and later Brazilian spotted fever (BSF). It is currently considered a disease for which notification is compulsory, and Amblyomma sculptum (previously referred to as Amblyomma cajennense) and Amblyomma aureolatum ticks are the main transmission vectors (PINTER; LABRUNA, 2006; KRAWCZAK et al., 2014). Dogs are frequently parasitized by these tick species and are therefore important sentinels for disease surveillance (PAROLA et al., 2013).

Most cases of BSF occur in southeast Brazil (SANGIONI et al., 2005; CUNHA, 2009). In 2008, a human fatality, attributed to this disease, likely resulted from an infection at the campus of the Rural Federal University of Rio de Janeiro (UFRRJ) in the Seropédica municipality (data provided by the Secretary of Health, Health Surveillance Sector, Municipal Prefecture of Seropédica).

The objective of this study was to investigate the presence of anti-Rickettsia antibodies in canines from the municipality of Seropédica, to determine the distribution of Rickettsia among dogs based on traits, (such as breed, age subgroups, and gender), and to identify the Ixodidae species parasitizing the dogs.

A descriptive epidemiologic study was performed between October 2010 and April 2011 in the municipality of Seropédica (latitude $22^{\circ} 44^{\prime}$ $38^{\prime \prime} \mathrm{S}$, longitude $43^{\circ} 42^{\prime} 28^{\prime \prime} \mathrm{E}$ ) located in the western region of Baixada Fluminense, Metropolitan Mesoregion in RJ, Brazil. The municipality is situated 33 meters above sea level and covers an area of $283,794 \mathrm{~km}^{2}$, with an estimated population of 78,183 inhabitants in 2011. The main UFRRJ campus is located in Seropédica, and is considered the largest university campus in Latin America, covering approximately 3,024 hectares. On the campus, secondary vegetation includes pastures, forest fragments, and areas of low vegetation, with native and introduced species, reforestation species, and various species of eucalyptus, and the landscape is classified as a littoral plain. Several species of domiciliary and wild animals are found throughout this region, including canines, equines, bovines, rodents, etc. Among the wild animals implicated as reservoirs for various pathogens are capybaras (Hydrochoerus hydrochaeris), opossums (Didelphis aurita), agoutis (Dasyprocta aguti), Brazilian guinea pigs (Cavia aperea), and ninebanded armadillos (Dasypus novemcinctus).

The number of animals sampled was determined using the simple random sampling formula, with a $95 \%$ confidence interval, maximum error of $5 \%$, and estimated prevalence of $15.91 \%$ (according to a pilot study using 44 animals from the municipality). The minimum sample number in the urban areas (areas 1 to 3) was estimated at 206 animals. The dog blood samples were collected in areas corresponding to a set of neighborhoods recognized by the local inhabitants as follows: area 1, "Km 40," 90 animals; area 2, "Km 49," 86 animals; and area 3, "Km 54," 32 animals. Area 4 corresponded to the UFRRJ campus, from where 75 serum samples were collected, including samples from 45 dogs residing in the Ecology Neighborhood and 30 communal dogs. The number of samples collected from animals in the three urban areas was proportional to the average number of dogs vaccinated in 2008 and 2009 (data provided by the Secretary of Health, Health Surveillance Sector, Municipal Prefecture of Seropédica). Dogs of all ages (from 6 months old), 
both genders, healthy in appearance, and mostly of undefined breeds were analyzed. Free-roaming animals residing around the UFRRJ lodgings that were fed by academic students from the university were considered communal. An epidemiologic questionnaire was administered to the owners of domiciliary animals; it was individually tailored for each animal to obtain information on the dogs and breeding routines.

During the collections, the canines were searched for the presence of ticks, mainly in the ears, back, and palmar and plantar pads. Specimens were removed either manually or with the help of ophthalmic tweezers, and forwarded to the UFRRJ Laboratory of Parasitic Diseases for taxonomic identification. The identification key proposed by Battesti et al. (2006) was used. Then, the specimens were stored in a freezer at $-20^{\circ} \mathrm{C}$ until the genetic material was extracted according to a previously described protocol (FERREIRA, 1996).

The serological analysis was performed in the Tick Laboratory of the Superintendency for the Control of Endemic Diseases of the State of São Paulo (SUCEN-SP) located in the Mogi Guaçu municipality, SP. All samples were tested using indirect immunofluorescence assay (IFA) against the $R$. rickettsia Taiaçu strain antigen (PINTER; LABRUNA, 2006) according to the methods of Horta et al. (2007). The serum sample from an animal naturally infected with $R$. rickettsia with a titer of 1:8,192 was used as a positive control and was provided by Dr. Jonas Moraes-Filho (FMVZ/ USP). A sample of canine serum that was previously tested and stored at $-20^{\circ} \mathrm{C}$ was used as a negative control.

The extracted DNA was subjected to polymerase chain reaction(PCR); specifically, a 532-bp sequence of the ompA gene was amplified using the primers
Rr190.70p (ATGGCGAATATTTCTCCAAAA) and Rr190.602n (AGTGCAGCATTCGCTCCCCCT) according to the protocol previously described by Labruna et al. (2004). One positive control (DNA from the NOD strain of $R$. parkeri) and two negative controls (water) were used for each reaction. For all variables of interest, the relative and absolute frequencies were calculated for a descriptive analysis.

The questionnaire results were compared with the IFA results using Fisher's exact tests with a 95\% confidence level. The communal animals were not assessed with respect to age.

Of the 283 serum samples tested by IFA, $24.0 \%$ (68/283) reacted against the $R$. rickettsii antigen, and the observed prevalence was $20.0 \%(18 / 90)$ in area $1,22.1 \%(19 / 86)$ in area 2, 28.1\% (9/32) in area 3 , and $29.3 \%(22 / 75)$ in area 4 . The positivity of the samples varied among the dilutions tested, between 1:64 and 1:512, and more than half of the animals tested $(54.4 \%)$ were seropositive at 1:64. No significant difference was observed in the variables tested (Table 1).

The results of the present study are consistent with those obtained by Cunha (2009), who evaluated $R$. rickettsii infection in 105 serum samples from dogs in the Resende Municipality, RJ, an endemic region for $\mathrm{BSF}$, and found $27.62 \%$ positive titers that varied between 1:64 and 1:4,096. Values near to or greater than those found in this study have also been observed in endemic areas from other Brazilian localities (LEMOS et al., 1996; SANGIONI et al., 2005; HORTA et al., 2007). Lower prevalence of Rickettsia than those estimated in this study were observed in dogs from rural (11.6\% ) and urban areas $(3.9 \%)$ in the Municipality of Monte Negro, State of Rondônia, that tested positive for at least one of the six species of Rickettsia examined (LABRUNA et al., 2007). 
Table 1. Results of indirect immunofluorescence assay (IFA) for detection of IgG anti Rickettsia rickettsii in dogs according to type of breeding (chained or free), age and sex. Serum samples from dogs at the municipality of Seropédica State of Rio de Janeiro, collected in the period from October 2010 to april 2011.

\begin{tabular}{|c|c|c|c|c|c|c|c|}
\hline \multirow{2}{*}{$\begin{array}{l}\text { Variable } \\
\text { Area } \\
\end{array}$} & & \multicolumn{2}{|c|}{ Sex } & \multicolumn{2}{|c|}{ Type of breeding } & \multicolumn{2}{|c|}{ Age } \\
\hline & & Male & Female & Chained & Free & $\leq 1$ year old & $>1$ year old \\
\hline \multirow{3}{*}{ Area $1-\mathrm{Km} 40$} & $\mathrm{P}$ & $7(7,8 \%)$ & $11(12,2 \%)$ & $8(8,9 \%)$ & $10(11,1 \%)$ & $1(1,1 \%)$ & $17(18,9 \%)$ \\
\hline & $\mathrm{N}$ & $31(34,4 \%)$ & $41(45,6 \%)$ & $40(44,4 \%)$ & $32(35,6 \%)$ & $16(17,8 \%)$ & $56(62,2 \%)$ \\
\hline & Total & $38(42,2 \%)$ & $52(57,8 \%)$ & $48(53,3 \%)$ & $42(46,7 \%)$ & $17(18,9 \%)$ & $73(81,1 \%)$ \\
\hline \multirow{3}{*}{ Area $2-\mathrm{Km} 49$} & $\mathrm{P}$ & $9(10,5 \%)$ & $10(11,6 \%)$ & $5(5,8 \%)$ & $14(16,3 \%)$ & $5(5,8 \%)$ & $14(16,3 \%)$ \\
\hline & $\mathrm{N}$ & $28(32,6 \%)$ & $39(45,3 \%)$ & $25(29,1 \%)$ & $42(48,8 \%)$ & $11(12,8 \%)$ & $56(65,1 \%)$ \\
\hline & Total & $37(43,0 \%)$ & $49(57,0 \%)$ & $30(34,9 \%)$ & $56(65,1 \%)$ & $16(18,6 \%)$ & $70(81,4 \%)$ \\
\hline \multirow{3}{*}{ Area $3-\mathrm{Km} 54$} & $\mathrm{P}$ & $3(9,4 \%)$ & $6(18,8 \%)$ & $5(15,6 \%)$ & $4(12,5 \%)$ & $2(6,3 \%)$ & $7(21,9 \%)$ \\
\hline & $\mathrm{N}$ & $12(37,5 \%)$ & $11(34,4 \%)$ & $6(18,8 \%)$ & $17(53,1 \%)$ & $3(9,4 \%)$ & $20(62,4 \%)$ \\
\hline & Total & $15(46,9 \%)$ & $17(53,1 \%)$ & $11(34,4 \%)$ & $21(65,6 \%)$ & $5(15,7 \%)$ & $27(84,3 \%)$ \\
\hline \multirow{3}{*}{$\begin{array}{l}\text { Area } 4 \text { - } \\
\text { UFRRJ campus }\end{array}$} & $\mathrm{P}$ & $10(13,3 \%)$ & $12(16,0 \%)$ & $2(2,7 \%)$ & $20(26,7 \%)$ & $6(13,3 \%)$ & $13(28,9 \%)$ \\
\hline & $\mathrm{N}$ & $26(34,7 \%)$ & $27(36,0 \%)$ & $13(17,3 \%)$ & $40(53,3 \%)$ & $5(11,1 \%)$ & $21(46,7 \%)$ \\
\hline & Total & $36(48,0 \%)$ & $39(52,0 \%)$ & $15(20,0 \%)$ & $60(80,0 \%)$ & $11(24,4 \%)$ & $34(75,6 \%)$ \\
\hline \multirow{3}{*}{ Total sample } & $\mathbf{P}$ & $29(10,2 \%)$ & $39(13,8 \%)$ & $20(7,1 \%)$ & $48(17,0 \%)$ & $14(5,6 \%)$ & $49(19,8 \%)$ \\
\hline & $\mathbf{N}$ & $97(34,3 \%)$ & $118(41,7 \%)$ & $84(29,7 \%)$ & $131(46,2 \%)$ & $35(14,1 \%)$ & $150(60,5 \%)$ \\
\hline & Total & $126(44,5 \%)$ & $157(55,5 \%)$ & $104(36,7 \%)$ & $179(63,3 \%)$ & $49(19,8 \%)$ & $199(80,2 \%)$ \\
\hline
\end{tabular}

$\mathrm{P}=$ positive; $\mathrm{N}=$ negative.

The higher prevalence found in dogs from rural areas is possibly linked to the higher tick diversity in these regions than in urban areas, where the $R$. sanguineus tick population is prevalent, as reported by Labruna et al. (2005). Conversely, higher seroprevalence estimates were found in areas where dogs are known to be the primary hosts of the $A$. aureolatum tick than in the areas examined in the present study. A $69.6 \%$ prevalence of animals reactive to $R$. rickettsii antigens, with titers varying between 1:256 and 1:32,768, was found in the municipality of Santo André, SP by Moraes et al. (2009), and $64 \%$ of seropositive dogs presenting titers ranging between 1:64 and 1:4,096 were found in the Mogi das Cruzes/SP municipality by Pinter et al. (2008).

In the municipality of Santa Cruz do Escalvado, a low-endemic area for BSF in the State of Minas Gerais, Milagres et al. (2010) reported that 20.89\% $(14 / 67)$ of the canines tested positive against $R$. rickettsii antigens. In addition to canines, serum samples from equines, opossums, and small rodents were also analyzed, revealing the circulation of rickettsiae in the area. Despite the positive reaction against $R$. rickettsii antigens, in this study $R$. felis was the only species that was detected by PCR.

In this study, the areas with the highest prevalence (areas 3 and 4) were less urbanized than the other areas. Moreover, the $29.3 \%$ prevalence found in area 4 may be related to the increased contact between dogs, equines, and free-roaming capybara populations, since the observed seroprevalence was consistent with that of BMF endemic areas, where the A. sculptum tick is the main transmission vector. Technically, IFA does not enable precise identification of the circulating rickettsial agent; therefore, it was only possible to identify the presence of antibodies for spotted fever group (SFG) rickettsiae, such as $R$. felis and $R$. parkeri.

The data obtained from the questionnaire administered to the owners of domiciliary animals revealed that 48 out of the 68 IFA-reactive animals had free access to the outdoors. The findings for area 4 are of particular interest because there was an increased tendency of the animals, with access to 
the outdoors, to be seroreactive (Table 1), and this particular area was frequented by an individual who perished from BSF. Access to the outdoors facilitates contact with stray dogs and areas used by bovine, equine, and wild animals, thereby increasing the probability that domiciliary dogs become infected by different species of tick and therefore increasing the probability of infection by Rickettsia spp.

No detectable difference was observed with respect to gender, demonstrating that this factor does not influence the probability of $R$. rickettsia infection in these animals (Table 1). Evaluating the relationship between seropositivity and age, the results indicated that seroreactive animals were older than 1 year old (Table 1). These data are similar to those reported by Pinter et al. (2008) and Cunha (2009) and can be explained based on the time required for seroconversion and the increased probability of contact with ticks over time.
Regarding the tick species, 66.78\% (189/283) of the dogs evaluated were infected with Ixodidae at the time of sample collection, and 43 of the 67 seroreactive animals were parasitized. The most abundant species was Rhipicephalus sanguineus (Table 2). The presence of $R$. rickettsii in this tick, identified using molecular techniques (CUNHA, 2009; MORAES et al., 2009), indicates a potential role of this species in the BMF epidemiological chain. There was a low prevalence of Amblyomma sculptum (Table 2). This species shows low host specificity at immature stages; it is typical of rural areas and uses equines, tapirs, and capybaras as its primary hosts. Dogs infested with A. sculptum had free access to the outdoors and therefore frequently visited pastures and wastelands in which equines graze.

Table 2. Ticks collected from dogs in 4 areas in Municipality of Seropédica in the State of Rio de Janeiro.

\begin{tabular}{|c|c|c|c|c|c|c|c|c|c|}
\hline \multirow{2}{*}{ Species of ticks } & \multicolumn{2}{|c|}{$\begin{array}{c}\text { Area 1 } \\
\text { "km 40" }\end{array}$} & \multicolumn{2}{|c|}{$\begin{array}{l}\text { Area } 2 \\
\text { "Km 49" }\end{array}$} & \multicolumn{2}{|c|}{$\begin{array}{c}\text { Area 3 } \\
\text { "Km 54" }\end{array}$} & \multicolumn{2}{|c|}{$\begin{array}{c}\text { Area } 4 \\
\text { "UFRRJ campus" }\end{array}$} & \multirow[t]{2}{*}{ Total ticks } \\
\hline & $\hat{\sigma}$ & q & $\widehat{0}$ & q & $\sigma^{\lambda}$ & 우 & $\sigma^{\top}$ & 우 & \\
\hline Amblyomma sculptum & 0 & 0 & 2 & 0 & 0 & 0 & 1 & 7 & $10(1,29 \%)$ \\
\hline Rhipicephalus sanguineus & 78 & 90 & 147 & 113 & 34 & 37 & 55 & 74 & $610(78,91 \%)$ \\
\hline Nymphs of Amblyomma sp. & \multicolumn{2}{|c|}{0} & \multicolumn{2}{|c|}{3} & \multicolumn{2}{|c|}{0} & \multicolumn{2}{|c|}{15} & $17(2,20 \%)$ \\
\hline Nymphs of $R$. sanguineus & \multicolumn{2}{|c|}{35} & \multicolumn{2}{|c|}{38} & \multicolumn{2}{|c|}{10} & \multicolumn{2}{|c|}{0} & $83(10,74 \%)$ \\
\hline Larvae & \multicolumn{2}{|c|}{4} & \multicolumn{2}{|c|}{4} & \multicolumn{2}{|c|}{0} & \multicolumn{2}{|c|}{8} & $16(2,07 \%)$ \\
\hline Total ticks & \multicolumn{2}{|c|}{81} & \multicolumn{2}{|c|}{307} & \multicolumn{2}{|c|}{207} & \multicolumn{2}{|c|}{178} & $773(100 \%)$ \\
\hline
\end{tabular}

In the present study, none of the tick samples showed amplification of ompA-specific bands by PCR using primers developed for SFG rickettsiae. SFG bacteria have a deleterious effect on Ixodidae, and this is a possible explanation for the result. For this reason, the observed frequencies in epidemiological studies in Brazil are around 1\% (CUNHA, 2009; PINTER; LABRUNA, 2006).

A small fraction of the owners reported frequently taking their animals to the veterinarian, usually when they become ill, and $76.65 \%$ said that they treat the animals themselves against ticks and fleas. However, the same owners reported difficulty in controlling arthropod infestations, and $90.87 \%$ claimed to detect fleas or ticks very frequently.

The presence of antibodies against $R$. rickettsii in dogs from the municipality of Seropédica, RJ, even at low titers, suggests the circulation of rickettsiae of the SFG in this area, indicating a need for permanent surveillance due to the extensive 
movement of people at the UFRRJ campus and adjacent areas.

\section{Acknowledgements}

The authors thank the Research Support Foundation of the State of Rio de Janeiro, FAPERJ for the financial support, the BBP Scholarship and the Coordination for the Improvement of Higher Education Personnel, and MEC for the first author's Masters Scholarship.

\section{References}

BATTESTI, D. M. B.; ARZUA, M.; BECHARA, G. H. Carrapatos de importância médico-veterinária da região neotropical: um guia ilustrado para identificação de espécies. São Paulo: Vox/ICTTD-3/Butantan, 2006. 223 p.

CUNHA, N. C. Estudo epidemiológico de rickettsias do grupo da febre maculosa em caninos, equinos e seus carrapatos no Município de Resende, Estado do Rio de Janeiro, Brasil. 2009. Tese (Doutorado em Ciências Veterinárias) - Universidade Federal Rural do Rio de Janeiro, Seropédica.

FERREIRA, M. E. G. D. Introdução ao uso de marcadores moleculares em análise genética. [S.1.]: EMBRAPA-CENARGEN, 1996. 220 p.

HORTA, M. C.; LABRUNA, M. B.; PINTER, A.; LINARDI, P. M.; SCHUMAKER, T. S. Rickettsia infection in five areas of the state of São Paulo, Brazil. Memórias do Instituto Oswaldo Cruz, Rio de Janeiro, v. 102, n. 7, p. 793-801, 2007.

KRAWCZAK, F.; NIERI-BASTOS, F.; NUNES, F.; SOARES, J.; MORAES-FILHO, J.; LABRUNA, M. B. Rickettsial infection in Amblyomma cajennense ticks and capybaras (Hydrochoerus hydrochaeris) in a Brazilian spotted fever-endemic area. Parasites \& Vectors, London v. 7, n. 1, p. 1-7, 2014.

LABRUNA, M. B.; CARMARGO, L. M. A.; TERRASSINI, F. A.; FERREIRA, F.; SHUMAKER, T. S.; CAMARGO, E. P. Ticks (Acari: Ixodidae) from the state of Rondônia, western Amazon, Brazil. Systematic and Applied Acarology, London, v. 10, n. 1, p. 17-32, 2005.
LABRUNA, M. B.; HORTA, M. C.; AGUIAR, D. M.; CAVALCANTE, G. T.; PINTER, A.; GENNARI, S. M.; CAMARGO, E. P. Prevalence of Rickettsia infection in dogs from the urban and rural areas of Monte Negro municipality, Western Amazon, Brazil. Vector-Borne Zoonotic Disease, Larchmont, v. 7, n. 2, p. 249-255, 2007.

LABRUNA, M. B.; WHITWORTH, T.; HORTA, M. C.; BOUYER, D. H.; MCBRIDE, J. W.; PINTER, A.; POPOV, V.; GENNARI, S. M.; WALKER, D. H. Rickettsia species infecting Amblyomma cooperi ticks from an area in the State of São Paulo, Brazil, where brazilian spotted fever is endemic. Journal of Clinical Microbiology, Washington, v. 42, n. 1, p. 90-98, 2004.

LEMOS, E. R. S.; MELLES, H. H. B.; COLOMBO, S.; MACHADO, R. D.; COURA, J. R.; GUIMARÃES, A. A.; SANSEVERINO, S. R.; MOURA, A. Primary isolation os spotted fever group from Amblyomma cooperi colleted from Hydrochaeris hydrochaeris in Brazil. Memórias do Instituto Oswaldo Cruz, Rio de Janeiro, v. 91, n. 3, p. 273-275, 1996.

MILAGRES, B. S.; PADILHA, A. F.; BARCELOS, R. M.; GOMES, G. G.; MONTANDON, C. E.; PENA, D. C. H.; BASTOS, F. A. N.; SILVEIRA, I.; PACHECO, R.; LABRUNA, M. B.; BOUYER, D. H.; FREITAS, R. N.; WALKER, D. H.; MAFRA, C. L.; GALVAO, M. A. M. Rickettsia in synanthropic and domestic animals and their hosts from two areas of low endemicity for Brazilian Spotted Fever in the Eastern Region of Minas Gerais, Brazil. Americam Jounal of Tropical Medicine and Hygine, Cleveland, v. 83, n. 6, p. 1305-1307, dec. 2010.

MORAES, J.; PINTER, A.; PACHECO, R. C.; GUTMANN, T. B.; BARBOSA, S. O.; GONZALES, M.; MURARO, M. A.; CECILIO, S. R. M.; LABRUNA, M. B. New epidemiological data on Brazilian Spotted Fever in an endemic area of the State of Sao Paulo, Brazil. Vector-Borne Zoonotic Disease, Larchmont, v. 9, n. 1, p. 73-78, 2009.

PAROLA, P.; PADDOCK, C. D.; SOCOLOVSCHI, C.; LABRUNA, M. B.; MEDIANNIKOV, O.; KERNIF, T.; ABDAD, M. Y.; STENOS, J.; BITAM, I.; FOURNIER, P. E.; RAOULT, D. Update on tick- Borne Rickettsioses around the world: a geographic approach. Clinical Microbiology Review, New York, v. 26, n. 4, p. 657-702, 2013. 
PINTER, A.; HORTA, M. C.; PACHECO, R. C.; MORAES-FILHO, J.; LABRUNA, M. B. Serosurvey of Rickettsia spp. in dogs and humans from an endemic area for Brazilian spotted fever in the State of São Paulo, Brazil. Cadernos de Saúde Pública, Rio de Janeiro, v. 24, n. 2, p. 247- 252, 2008.

PINTER, A.; LABRUNA, M. B. Isolation of Rickettsia rickettsii and Rickettsia bellii in cell culture from the tick Amblyomma aureolatum in Brazil. Annals of the New York Academy of Sciences, New York, v. 1078, n. 1, p. 523-529, 2006.
SANGIONI, L. A.; HORTA, M. C.; VIANNA, M. C. B.; GENNARI, S. M.; SOARES, R. M.; GALVAO, M. A. M.; SCHUMAKER, T. T. S.; FERREIRA, F.; VIDOTTO, O.; LABRUNA, M. B. Rickettsial infection in animals and Brazilian spotted fever endemicity. Emerging Infectious Diseases, Atlanta, v. 11, n. 2, p. 265-270, 2005. 
